\title{
AFORYZMY BIBLIJNE O ŻYCIU BOGOBOJNYM
}

Zbawiciel nasz często ubierał nauki religijno-moralne w piękną i przystępną formę praktycznych reguł życiowych. By wskazać np. na konieczność cnoty pokory, posługuje się przypowieścią o zaproszonych na ucztę (Łuk. 14,7-11). Ten sposób nauczania nie był dla żydów nowością. Spotykamy bowiem również w Starym Testamencie obok religijno-moralnych nauk w słowie i przykładzie szereg cennych wskazówek odnoszących się do życia czysto naturalnego i do umiejętnego obcowania $z$ ludźmi, a podawanych w formie krótkich aforyzmów. Dwie księgi kanonu, księga Przysłów i księga Jezusa Syracha (Ekklezjastyk), zajmują się nawet wyłącznie takimi regułami uczciwego życia. Zawarte w nich sentencje pochodzą w wielkiej części najprawdopodobniej z mniejszych, istniejących już dawniej zbiorów, a ponieważ tradycja przypisywała ich autorstwo Salomonowi, nie jest rzeczą wykluczoną, że przynajmniej niektóre $\mathrm{z}$ nich sięgają aż tak dalekiej przeszłości, t. j. X w. przed Chr., zwłaszcza, że I Król. 5, 9-14 wyraźnie wspomina o ułożonych przez Salomona przysłowiach i pieśniach. Na powstanie księgi Jezusa Syracha, pochodzącej z początku II w. przed Chrystusem, wpłynęła widocznie jeszcze i ta okoliczność, że autor chciał się przeciwstawić wdzierającym się coraz bardziej w życie izraelskie pogańskim prądom hellenistycznym i ich zgubnemu wpływowi na pobożność swych ziomków i zebrał 'w tym celu wszystko, co stanowiło dorobek myśli religijno-obyczajowej swego narodu, w krótkie ale treściwe reguły, normujące zasadnicze obowiązki względem Boga i bliźniego i wskazujące na ich konkretny wyraz w życiu codziennym, by w tej znanej, a powszechnie lubianej formie uprzystępnić zachwianym w życiu religijnym naukę Ojców i uczynić ją bardziej pociągającą.

Ta forma nauczania nie była jednak wyłączną własnością mędrców żydowskich. Znana ona była równiè i w Egipcie, jak o tym świadczy pochodząca z ok. r. 1000 przed Chr. księga Amen-en-ope ${ }^{1}$ ) oraz podobne zbiory, sięgające nawet 3 tysiąclecia. Również literatura assyryjsko-babilońska wykazuje szereg takich tekstów. Jest więc ten rodzaj literacki ogólną własnością starożytnego Wschodu, w Izraelu zaś doprowadzono go do formy najdoskonalszej. Bo tė̇ w czasach późniejszych wytworzył się tu specjalny stan mędrców (chakham), którzy na wspólnych zebraniach dyskutowali nad różnymi ogólnie znanymi po-

1) Por. przekład polski prof. Śmieszka w: Wielkiej Literaturze Powszechnej V, 146-148. 
wiedzeniami i nadawali im odpowiednią formę (Koh. 12, 11), by je potem uczynić przedmiotem publicznego nauczania (Koh. 12, 9; Syr. $38,33-39,11)$.

Przedmiotem zawartych w tych przysłowiach czy aforyzmach rad i pouczeń są najrozmaitsze dziedziny życia, najczęściej zaś omawiane w mich są: mądrość i głupota, sprawiedliwość i niesprawiedliwość, pobożność i bezbożność, pycha i pokora, uczciwość i nieuczciwość, miłość i nienawiść, gniew i łagodność, bogactwo i ubóstwo, pilność i lenistwo, stosunek Boga do człowieka, rodziców do dzieci, króla do poddanych, męża do żony, pana do służącego, wreszcie stosunki między przyjaciólmi. Celem zaś autorów jest wychowanie człowieka do roztropnego, a radosnego pielęgnowania pobożności w życiu codziennym i do praktycznej miłości bliźniego.

Przyjrzyjmy się niektórym $\mathrm{z}$ tych aforyzmów bliżej. Przede wszystkim jako początek wszelkiej mądrości przedstawiona jest w St. Testamencie bojaźń B o ża:

„Bojaźń Pana jest początkiem poznania, mądrości i nauki, z której głupcy się śmieją" (Przysł. 1, 7).

W pięknych słowach sławi ją Syrach: „Który to ród jest godny czci? - Ród ludzki!

A jaki ród? - Tych, co się Boga boją!

Który to ród jest pozbawiony czci? - Ród ludzki!

A jaki ród? - Tych, co przekraczają przykazania!

Pośród swych braci jest ich panujący we czci,

ale kto Boga się boi, czczony jest w J e go oczach.

Czy bogacz i możny, czy też biedny:

ich chlubą jest tylko bojaźń Boża“ (10, 19-22).

Ważniejszą ona jest, niż bogactwa:

„Bogactwo i sława podnosza na duchu,

ale cenniejszą od nich jest bojaźń Boża“ $(40,25)$.

Przy tym podkreśla się konieczność w e w n ęt r z n e j pobożności, przypominając napomnienia wielkich proroków. Tak czytamy u Syracha $34(31), 21-23$ :

„Otiara z nieprawych dóbr jest darem na urągowisko,

nie znajdą upodobania dary bezbożnych.

Nie ma upodobania Najwyzszy w darach bezbożników, ani też grzechów nie odpuści dla samego mnóstwa ofiar".

Dlatego też:

„Nie mów: ON na mnóstwo darów moich spojrzy,

a kiedy Bogu, Najwyższemu, złożę ofiarę,

wtedy ją przyjmie“ $(7,9)$. 
Wyraźniej jeszcze napomina Kohelet 4,$17 ; 5,1$ :

„Zważaj na krok swój, gdy idziesz do domu Bożego,

i zbliżaj się tam, aby słuehać;

tedy lepszą, niż dary głupców, będzie ta twoja ofiara,

bo ci nie umieją inaczej, jak źle postępować“.

Wreszcie Przysł. 21, 3:

„Milszym jest Panu przestrzeganie prawa i sprawiedliwości, niż całopalne ofiary".

Wśród obowiązków względem bliźnich stawia się na pierwszym miejscu szacunek i miłość w z g l ęd e m r o d z i c ó w. $\mathrm{Na}$ tym punkcie etyka naturalna stała wysoko nie tylko w narodzie izraelskim, ale u wszystkich ludów starożytnego Wschodu. Toteż często spotykamy się z napomnieniami do przestrzegania przykazania Bożego, a Syrach objaśnia przy tym związaną z tym przykazaniem obietnicę błogosławieństwa:

„Na prawo ojca zważajcie, synowie,

i według niego postępujcie, byście zbawienia dostąpili!

Pan bowiem dal ojcu szacunek $u$ dzieci

i prawo matki wobec dzieci ustalił.

Kto ojca szanuje, czyni zadość za grzechy,

a kto we czci ma matkę, podobny jest do tego,

co skarby gromadzi.

Kto ojca swego czci, doczeka się pociechy z dziatek,

a gdy się modll, będzie wysluchany.

Kto ojea szanuje, ten długo żyć będzie,

a kto posłuszny jest Panu, ten czci swoją matkę.

Kto Pana się boi, ten czci swego ojca

i służy swoim rodzicom, jak panom" $(3,1-16)$.

Piękne zaś uzasadnienie tych napomnień zawarte jest dalej w wierszach $7,27-29$ :

„Z calego serca szanuj twego ojea

i nie zapomnij boleści twej matki.

Pomyśl, że bez nich byś nie istnial;

a ty - jakże im możesz odpłacić za to, co uczynili dla ciebie?"

Podobne myśli podaje Przysł. 19, 26; 23, 22; 30, 11; Tob. 4, 3־5. Zaszczytną pozycje ksiag mądrościowych stanowi silne akcentowanie obowiązku miłości i wierności względem bliźniego, zwłaszcza zaś względem bied $\mathrm{n} \mathrm{y} \mathrm{ch}$ i u c iśn i o n y c h. Im w pienwszym rzędzie przyznawają prawo do pomocy i opieki, przez co kontynuują zadanie proroków, obrońców biednych, wdów i sierót, co jest tym 
bardziej znamienne, gdy zważymy, jak do zagadnień tych ustosunkował się ówczesny świat pogański. O całe niebo przewyższa pod tym względem St. Testament ducha starożytnej Grecji, gdzie, jak podaje Plato (De legibus, lib. 2), pewien Ateńczyk wystapił nawet $\mathrm{z}$ wnioskiem, by państwo wydało ustawę, według której należałoby wszystkich biednych wypędzić z kraju. Jakże inaczej brzmi w porównaniu z tym Syr. 4, 1-10:

„Biednego, mój synu, nie pozbawiaj utrzymania,

i nie zwódź oczu potrzebujących!

Nie sprawiaj rozczarowania głodującemu

i nie drażnij czlowieka w jego ubóstwie!

Serca pełnego goryczy nie zasmucaj jeszcze bardziej

i nie skąp biednemu jałmużny!

Nie odrzucaj prośby człowieka, który popadł w nędzę,

i nie odwracaj oblicza twego od ubogiego!

Od proszącego nie odwracaj swych oczu

i nie dawaj nikomu powodu, by cię przeklinał!

Jeśli cię przeklnie w goryczy swej duszy,

wołania jego slucha Stwórca jego!

Zyskuj sobie względy wśród gminy,

a przed możnymi nie podnoś czoła!

Nakłoń ucha biednemu

i grzecznie odpowiadaj na jego ukłony!

Oskarżonego broń przed fałszywym donosicielem

i nie poddawaj śię słabości, gdy wydajesz wyrok!

Dla sierót bądź jakby ojcem

i zastąp miejsce męża ich matce!

Wtedy, Najwyższy synem zwać cię będzie

i umiłuje cię bardziej, niż własna matka twoja".

Również o chorych każe dbać, a nawet o zmarłych nie zapominać:

„Dla żyjącego miej łaskawy dar,

lecz i zmarłemu nie odmawiaj miłości!

Nie trzymaj się $z$ dala od placzących,

a ze smutnymi podzielaj smutek!

Niech ci. nie będzie trudno odwiedzać chorych,

boć. z tego względu doznajesz miłości!“ (7, 33-35).

W ostrych zaś słowach wyraża się o tych, co krzyıwdzą bliźniego:

„Syna uśmierca w oczach jego ojca

kto składa ofiarę $\mathrm{z}$ własności biednego.

Łaskawy chleb jest utrzymaniem biednych,

krwiożercą przeto jest, kto im go kradnie.

Morduje bliźniego, kto mu pożywienie odbiera,

a krew rozlewa, kto pracownikowi zarobek uszczupla“ (34/31), 24-27). 
W czynnej miłości bliźniego widzi mędrzec wyraz prawdziwej pobożności :

„Kto prawo zachowuje, ten wiele przynosi ofiar:

ofiarę zapokojną składa, kto przestrzega przykazań;

ofiarę bezkrwawą składa, kto miłość okazuje;

ofiarę dziękczynną składa, kto udziela jałmużny.

Upodobanie ma Pan w tym, kto się od zlego wstrzymuje,

a ofiarą zagrzeszną jest wystrzeganie się nieprawości" (35/32), 1-4).

Istota pobożności przedstawiona tu więc jest nie inaczej, jak później w liście św. Jakuba 1, 27: „Pobożność czysta i niepokalana u Boga $i$ Ojca jest ta: nawiedzać sieroty $i$ wdowy w ich ucisku, a siebie zachować nieskalanym od tego świata".

Dla życia osobistego zaleca Syrach pokorę i umiarkow a n i e, a przestrzega przed próżną pychą:

„Mój synu, skromnie do swoich spraw się zabieraj,

a wtedy będziesz lubianym u pobożnych ludzi!

Im wyżej się wzniesiesz, tym niżej się kłaniaj,

a znajdziesz łaskę u Pana!

Moc Pańska jest wielka,

a sławią ją ci, którzy przed Nim się korzą" (3, 17-19).

Pychę piętnuje równiė księga Przysłów:

„Olbrzydliwością jest dla Pana każdy pyszny,

jest rzeczą pewną, że nie ujdzie kary“ $(15,5)$.

„Pycha poniża człowieka,

pokorny zaś dojdzie do sławy“ $(29,23)$.

„Nagrodą pokory i bojaźni Pańskiej

jest sława, bogactwo i życie" $(22,4)$.

Do przypowieści P. Jezusa o zaproszonych na ucztę bardzo podobne są słowa Przysł. 25, 6-7:

Przed królem nie udawaj wielkiego

i nie siadaj na miejscu przeznaczonym dla możnych,

bo lepiej, że ci powiedzą: Posuń się wyżej;

niż, żeby cię mieli poniżyć przed kimś znaczniejszym".

Ciekawe są tė przepisy przyzwoitego zachowania się przy stole, zawarte u Syracha, 31 (34), 12-24. Przytoczyć zaś warto trafne jego wnioskowanie $z$ zewnętrznego wyglądu człowieka o wewnętrznej jego wartości:

„Poznasz czlowieka po jego wyglądzie,

a mądrego po wyrazie jego twarzy.

Ubiór człowieka i uśmiech jego zębów,

a nawet chód jego ci zdradzi, czym on jest". 
O wartości, jaką przedstawia w ie $\mathrm{r}$ y $\mathrm{p} \mathrm{r} \mathrm{z} \mathrm{y} \mathrm{j} \mathrm{a} \mathrm{c} \mathrm{i} \mathrm{e} \mathrm{l,} \mathrm{pisze}$ Syr. 6, 14-17:

„Wierny przyjaciel jest mocną ostoją,

a kto go znalazł, znalazł majątek.

$\mathrm{Na}$ przyjaciela wiernego nie masz ceny,

a jego wartości wagą nie zważysz.

Balsamem życiodajnym jest wierny przyjaciel,

a znajdzie go ten, kto Pana się boi.

Ten tylko, kto Pana się boi, prawdziwą utrzymuje przyjaźń,

bo jakim on sam jest, takim i jego przyjaciel".

Wreszcie zwrócić jeszcze warto uwagę na teksty, w których męđrzec szkicuje ty p y $\mathrm{k}$ obi e ce. I w nich również daje dowód, że $z$ otwartymi idzie oczyma przez życie. Zna on niebezpieczeństwa, jakie grożą człowiekowi ze strony złej niewiasty i usilnie przed nimi przestrzega (Syr 25, 13nn; 26, 6nn; Przysł. 5, 1nn; 6, 25nn; 21, 19). Tym jaśniejszych za to używa barw, by przedstawić zalety dobrej i wiernej żony. Dla przykładu przytoczmy Syr. 26, 1-4. 13-18:

„Szczęśliwy mąż dobrej żony, podwójna jest liczba dni jego życia.

Dzielna niewiasta rozwesela swego męża, w spokoju on spędza lata swego żywota.

Dobra niewiasta, to los szczęśliwy, przypada on tym w udziale, co Boga się boją.

Czy 'bogacz, czy biedny - radości pełne jest jego serce,

a jego oblicze zawsze pogodne.

Uroda żony zachwyca jej męża, a mądrość jej odświeża jego kości.

Niewiasta cicha darem jest Bożym, na dobrze wychowaną duszę nie masz ceny.

Wstydliwość niewiasty, to najpiękniejsza jej ozdoba, a duszy czystej nic nie dorówna.

Jak słońce świecące na wysokościach Pańskich, tak szlachetnej kobiety uroda jest ozdobą jej domu. Jak lampa płonąca na świętym świeczniku, tak wdzięki jej rysów na postaci wspaniałej. Czym złote kolumny na srebrnej podstawie, tym kształtne jej nogi na silnych stopach".

Podobne obrazy zawierają wiersze Syr. 36, 27-31; Przysł. 12, 4; 18,$22 ; 19,14$.

W końcu wspomnieć tu należy jeszcze o znanej perykopie Przysł. $31,10-31$, w której autor wysławia cnoty wzorowej żony i gospodyni domu: jej troskę o rodzinę, pracowitość, jej socjalne nastawienie w sto- 
sunku do służby i do biednych, zalety jej umysłu i jej pobożność. Są to ideały kobiece, pisane palcem Bożym, które nigdy nie tracą na swym znaczeniu.

Bielsko

Ks. KONRAD MARKLOWSKI.

\section{LAPIDES PRETIOSI OMNES MURI TUI \\ I.}

Wśród nieprzebranych skarbów przyrody od dawna człowiek poszukiwał ozdobnych kamieni, odznaczających się pięknem barw i przeźroczystością, żywym blaskiem i dużą łamliwością światła. Nazwano je kamieniami szlachetnymi i półszlachetnymi.

Gra światel i przepysznych barw, charakteryzująca tych skromnych w rozmiarach przedstawicieli ,,martwej przyrody“, czyni ich , żywymi “ dla ludzi wszystkich czasów na całej bodaj kuli ziemskiej. W ich pięknie niejeden natchniony wieszcz i piewca szukał wyrazu dla określenia piękna otaczających nas zjawisk.

Dlatego też i w Biblii spotykamy często wzmianki o kamieniach szlachetnych, które mieszkańcy ziemi palestyńskiej za przykładem całego Wschodu bardzo wysoko cenili, chociaż ich w kraju nie posiadali. Sprowadzano je $\mathrm{z}$ Arabii, Nubii i Indii, jak o tym świaidczą teksty historyczne. W księgach Pisma św. stały się one symbolami wielkich i wspaniałych myśli, zwłaszcza w O b j a w i en i úw. J a n a.

Kiedy Apostoł opisuje chwałę Boga a Władcy wszechświata, wspomina o kamieniach szlachetnych, których blask niejako widza oślepia i uwypukla majestat Boży. „I natychmiast $w$ zachwyt wpadfem - tak pisze 4, 2 - $i$ oto stał tron $w$ niebiosach $i$ na tronie ktoś siedziat, a Ten, który siedziat, byt wygladem podobny do kamienia jaspisowego i sardisowego, i tęcza była wkoło tronu i miała blask szmaragdu“.

Podobnymi słowy charakteryzuje św. Jan chwałe nowej Jerozolimy, która się zrealizuje przy końcu świata. Oto jego słowa $(21,10-20)$ :

„I zabrat mnie (Aniot) w ekstazie na górę wielka i wysokq $i$ pokazat mi nowe miasto Jeruzalem, zstępujace $z$ nieba od Boga, majace wyglad wspaniały, jak Bóg, a blask jego był równy blaskowi kamieni szlachetnych, równy jaspisowi, a jasny jak kryształ... A fundamenty muru miasta byty ozdobione wszelakim kamieniem szlachetnym, jedna 